\title{
Employee Admissions Information System Web-based at CV Galerindo Nusantara
}

\author{
$1{ }^{\text {st }}$ Edy Susena, ${ }^{2 \text { nd }}$ Edy Susanto, ${ }^{3 r d}$ Dwi Iskandar, ${ }^{\text {th }}$ Muhamad Handi Stiawan \\ ${ }_{1,2,3,4}$ Politeknik Indonusa Surakarta \\ 1,2,3,4 J1.KH. Samanhudi 31 Mangkuyudan, Surakarta \\ Surakarta, Indonesia \\ 1edysusena@poltekindonusa.ac.id, ${ }^{2}$ edy_skp@ poltekindonusa.ac.id, ${ }^{3} \mathrm{dwik} @$ poltekindonusa.ac.id, \\ ${ }^{4}$ muhamad.stiawan@poltekindonusa.ac.id
}

\begin{abstract}
CV Galerindo Nusantara company still uses manual methods in the recruitment process, namely prospective employees must come to the company to apply for work and still use paper so that companies need a computerized system that can facilitate employee recruitment activities. Based on these problems the authors seek solutions to make it easier for companies to overcome these problems. In developing this system, the author uses the waterfall method, namely the work of a system that is carried out sequentially or linearly. The results of the web-based employee recruitment information system at CV Galerindo Nusantara which was created by the author are to produce a system that can make it easier for prospective employees and companies to carry out computerized employee recruitment activities as well as time efficiency and make it easier for prospective employees to access information systems.
\end{abstract}

Keywords :System, Information, Employees, website

\section{INTRODUCTION}

The use of technology is now being used by various groups, one of which is a web-based information system. Almost all companies use a computerized system and take advantage of technology for the advancement of the company's business. The more sophisticated the technology used, the easier and faster the activities will be carried out in the business venture. The need for time and cost efficiency causes companies to feel the need to apply technology in their business. Human Resources (HR), namely as a driving force for an organization or company, if HR is not managed properly and is not properly managed to work together and synergize with each other, it is impossible for the organization or company to run properly and optimally as expected, it will but it must be understood and understood that humans are not like machines that work without feelings and are considered solely as a source of business energy to achieve an organizational or company goal[1] Galerindo Nusantara is one of the jobs in the field of food and beverage production. The establishment of Galerindo Nusantara was initially to meet the needs of food and beverage products in Indonesia. Galerindo Nusantara itself was first founded by Bintang Marsiwa Nusantara in 2018. Previously there was only a small restaurant on the side of the road called Ayam Bakar Bhesus. After several years finally established CV. Galerindo Nusantara which has two branches, namely Ayam Bakar Bhesus and GaleriPedas which is a restaurant in Surakarta. CV Galerindo Nusantara needs a system that can regulate and manage employee recruitment according to the company's needs. And in this era of increasingly sophisticated technological developments, the employee recruitment system at this company is still manual and there is no information system that makes it easy for prospective employees to apply for jobs where prospective workers do not need to manually write on paper to apply for jobs. Therefore, the authors want to provide a solution by creating a web-based information system to facilitate activities within the company. Based on developments, the existing service processes in the company can be developed with the help of system updates that can provide a new form of service so that the recruitment process is short without a longer process.

\subsection{Literature Review}

\section{System}

A system is a collection of people who work together with systematic and structured regulatory provisions to form a single unit that carries out a function to achieve a goal. The system has several characteristics or characteristics consisting of system components, system boundaries, external environment, liaisonsystem, system input, system output, system processing and system objectives[2].

\section{Information}

Information is data that is processed to be more useful and meaningful for the recipient, as well as to reduce uncertainty in the decision-making process regarding a situation[2]. Based on the above opinion, the writer concludes that information is data that has been processed into a more useful form and can be used as a basis for making the right decision.

\section{Information Systems}

Information systems are organized systems for the collection, organization, storage and communication of information.This system is used by people and organizations to collect, filter, process, create and distribute data into information [9]. produce some information for the user.

4. Employees

Employees are the main wealth of every company, because their role determines the success or failure of the company to achieve its goals. Companies must always try to obtain and place qualified employees in every position and job so that the implementation of work is more efficient and effective [6]. 
Peer Reviewed - International Journal

Vol :Vol. 02, Issue 02, May 2021

e-ISSN : 2745-9659

https://ijcis.net/index.php/ijcis/index

\section{Employee Reception}

Employee recruitment is guided by certain principles outlined by the internal and external companies, so that the implementation and results of the selection can be accounted for both legally and economically [6].

\section{Website}

A website is a set of pages consisting of several pages containing information in the form of digital data, whether in the form of text, images, video, audio and other animations provided through an internet connection.More specifically, websites are pages that contain information that can be accessed by browsers and are able to provide useful information for those who access them[8].

\section{XAMPP}

XAMPP is free software, which supports many operating systems, which is a compilation of several programs. The function of XAMPP itself is as a stand-alone server (localhost), which consists of several programs, including: Apache HTTP Server, MySQL database, and language translators written in the PHP and Perl programming languages[5].

\section{Database}

Databases are interconnected data that are grouped in a table or several tables and an application program that regulates how to access the data. Collections of this data are usually called databases, which contain real information, for example for a company[10].

\section{BASIC THEORY AND METHOD}

In this research method, there are 2 types of methods, namely data collection methods and systems development methods.

\subsection{Data Collection Methods}

The following are as follows: The data collection methods that the authors use are as follows:

a. Observation

Observation is an observation of a person's behavior in certain situations. This observation aims to assess the problem. Assessment can be said to be professional if it is done by monitoring the behavior of others visually while recording information from the behavior obtained qualitatively or quantitatively[7]. In this observation method, the writer observes directly the object of research, namely by observing the staffing and managerial departments to obtain accurate data in CV Galerindo Nusantara Surakarta..

\section{b. Interview Method}

The interview method is a process of conversation carried out by interviewers and interviewees with specific goals, with guidelines and can be face to face or through certain communication tools[3]. In this interview method, the author conducts questions and answers with the manager, namely Indah Pratiwi at CV Galerindo Nusantara which is related to the recruitment of employees to make references and flow in making information systems.

\section{c. Literature Study Method}

Literature study is a framework, concept or orientation for analyzing and classifying facts collected in the research conducted. Reference sources (books, journals, magazines) referred to should be relevant and up to date (state of art) and in accordance with those contained in Reference library[1]. In this literature study method, the authors collect data by reading books, literature, journals related to report writing.

\subsection{System Development Methods}

The system development method is a systematic or regular way that aims to analyze the development of a system so that the system can meet needs.In essence, the waterfall model system development method is the work of a system that is carried out sequentially or linearly.From the user side it is also more profitable because it can plan and prepare all the data and process requirements that will be needed.

\section{RESULT AND ANALYSIS}

\subsection{Needs Analysis}

At this stage of needs analysis, the writer made a system using the waterfall method.The analysis currently needed is a new system analysis because CV Galerindo Nusantara does not yet have a computerized employee recruitment system, namely the company only provides job vacancies and still uses paper for recruitment selection and applicants must come to the company with less effective procedures.So that the author wants to design and develop a new web-based information system that is effective using interconnected procedures.

\subsection{System Design}

The following is a system design at CV Galerindo Nusantara

\section{Context Diagram}

The following is a context diagram of the Web-Based Employee Admissions Information System at CV Galerindo Nusantara.

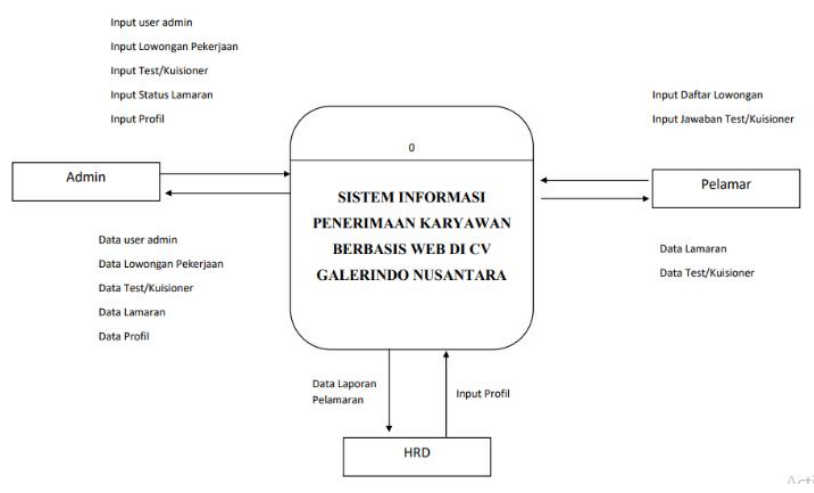

Figure 1. Context Diagram 
Peer Reviewed - International Journal

Vol :Vol. 02, Issue 02, May 2021

e-ISSN : 2745-9659

https://ijcis.net/index.php/ijcis/index

2. Tiered Diagram

The following is a diagrammatic diagram of a WebBased Employee Recruitment Information System at CV Galerindo Nusantara.

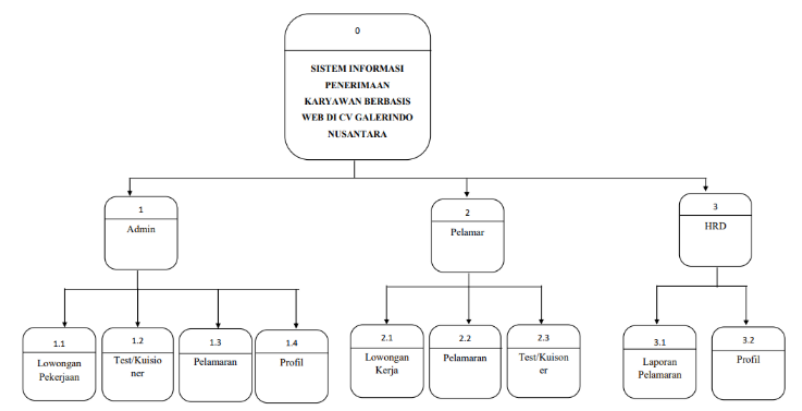

Figure2. Tiered Diagram

3. Data Flow Diagram (DAD) Level 0

The following is a picture of Level 0 Data Flow

Diagram (DFD) Information System for Web-Based

Employee Admissions at CV Galerindo Nusantara

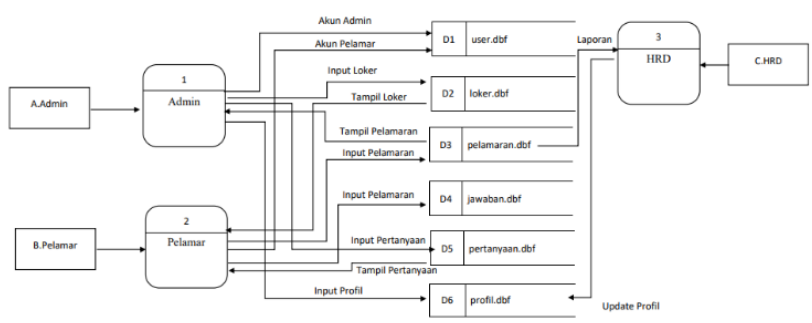

Figure3. DAD Level 0

4. Data Flow Diagram (DAD) Level 1

The following is a picture of Level 1 Data Flow Diagram (DFD) Information System for Web-Based Employee Admissions at CV Galerindo Nusantara.
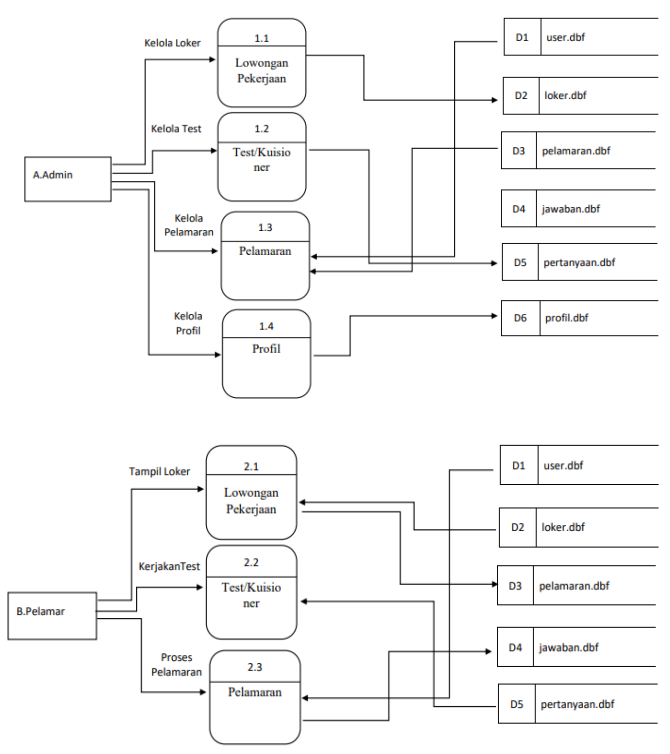

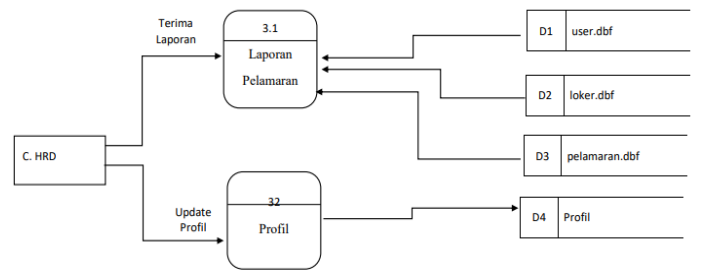

Figure 4. DAD Level 1

\subsection{System Implementation}

The following is an implementation of the web-based employee recruitment information system at CV Galerindo Nusantara.

1. Display Implementation Login

This login implementation functions to enter the system, if the user name and password match, then they can enter the system, if the user name and password do not match then they cannot enter the system.

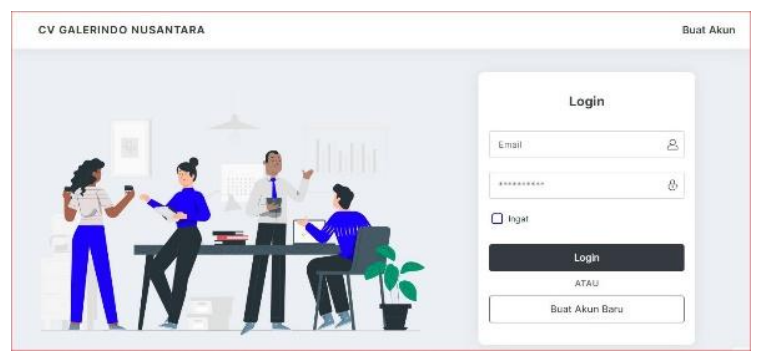

Figure 5. Login View

2. Display Admin Dashboard Implementation

On this page the admin can select the menu and view the data that has been entered by the user so that the admin can edit, create, change, and delete data from this system.
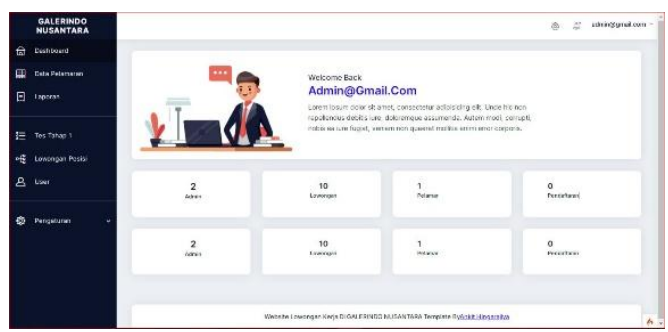

Figure 6. Admin Dashboard Display

3. Display Applicant Data Implementation

On this page, the admin can see the applicant's data input in the application details and the admin can change the applicant's status. 
Peer Reviewed - International Journal

Vol :Vol. 02, Issue 02, May 2021

e-ISSN : 2745-9659

https://ijcis.net/index.php/ijcis/index
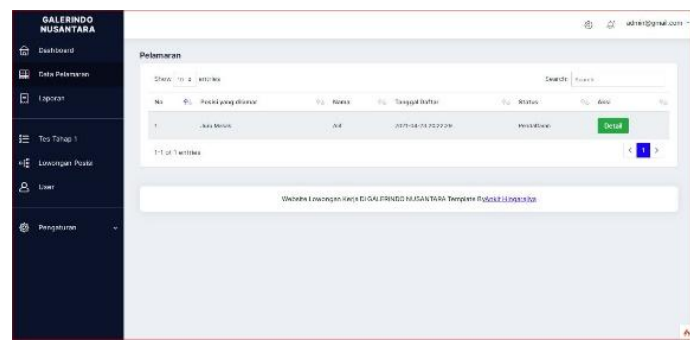

Figure 7. Applicant Data Display

4. Display Problem Test Implementation

In this menu, the admin can input questions for the test to applicants, namely in the form of multiple choice or essays.
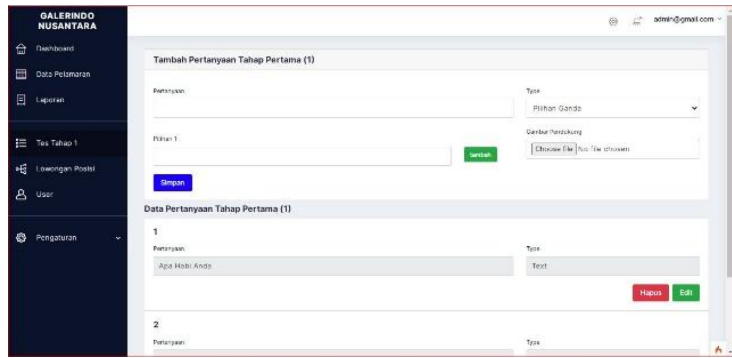

Figure 8. Display Test Questions

5. Job Vacancies Implementation Display

On this page, the Admin can enter a Job Vacancy required by the company.
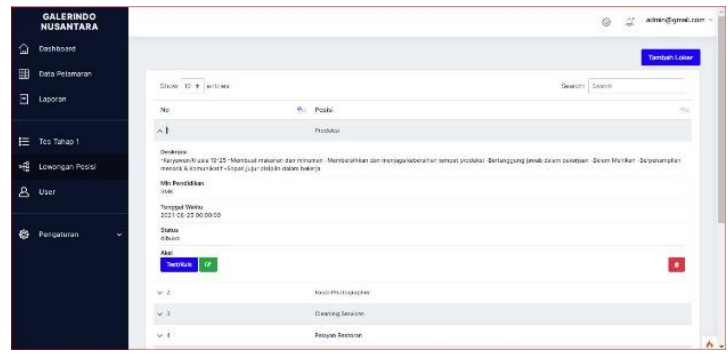

Figure 9. Job Position View

6. Display Registration Implementation

On this page, Applicants can create a new account to later $\log$ in to the job vacancies that have been provided.

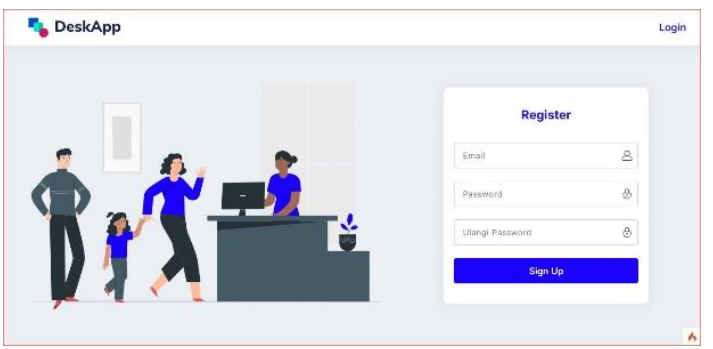

Figure 10. Registration Display

7. Applicant Dashboard Implementation Display

This page is the applicant's display when they have registered and logged into the system.

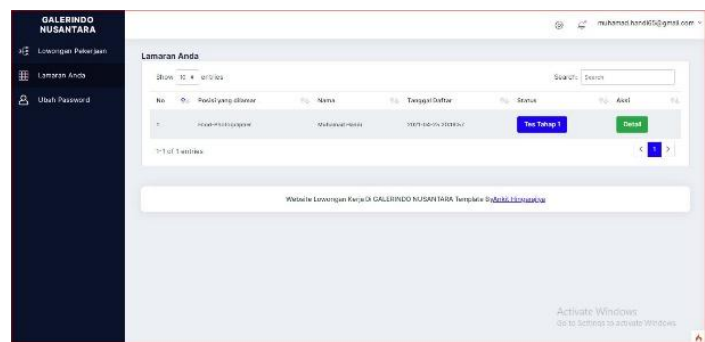

Figure 11. Applicant Dashboard View

8. Display HR Dashboard Implementation

The following is the HR dashboard display, on this page HRD can access the employee recruitment report.
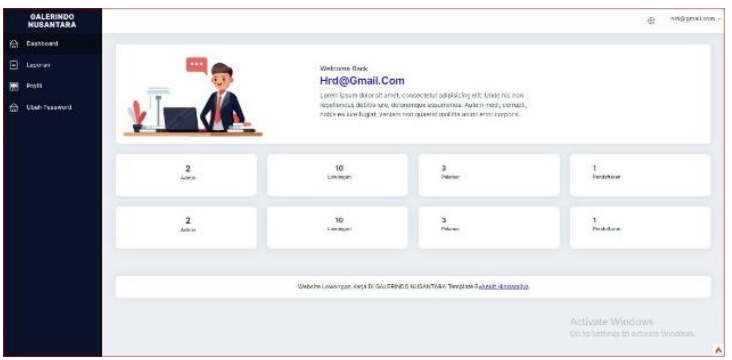

Figure 12. FigureDashboard Hrd

\subsection{System Testing}

This Web-based Employee Recruitment Information System, the authors conducted a test using the Black Box method, to achieve the goal that the system is feasible to use.Black Box testing focuses on the functional requirements of the software.Thus, this test makes it possible to obtain a set of input conditions that fully utilize the functional requirements for a program.The following is a table of system test results:

Table 1. System Testing Table

\begin{tabular}{clll}
\hline No & Process Design & Expected results & Result \\
\hline 1. & $\begin{array}{l}\text { Admin Login to } \\
\text { the admin page }\end{array}$ & $\begin{array}{l}\text { Successfully entered } \\
\text { the admin page }\end{array}$ & $\begin{array}{l}\text { was } \\
\text { successful }\end{array}$ \\
\hline 2. & $\begin{array}{l}\text { Admin can } \\
\text { Input Job Data }\end{array}$ & $\begin{array}{l}\text { Successfully Input } \\
\text { Job data }\end{array}$ & $\begin{array}{l}\text { was } \\
\text { successful }\end{array}$ \\
\hline 3. & $\begin{array}{l}\text { Admin can } \\
\text { view user data }\end{array}$ & $\begin{array}{l}\text { Successfully seen } \\
\text { user data }\end{array}$ & $\begin{array}{l}\text { was } \\
\text { successful }\end{array}$ \\
\hline 4. & $\begin{array}{l}\text { User can login } \\
\text { or register }\end{array}$ & $\begin{array}{l}\text { Successfully login } \\
\text { or register to the } \\
\text { system }\end{array}$ & $\begin{array}{l}\text { was } \\
\text { successful }\end{array}$ \\
\hline 5. & $\begin{array}{l}\text { User can input } \\
\text { data }\end{array}$ & $\begin{array}{l}\text { Successfully input } \\
\text { data }\end{array}$ & $\begin{array}{l}\text { was } \\
\text { successful }\end{array}$ \\
\hline & & &
\end{tabular}

\section{IV.CONCLUSION}

From the results and discussion that has been presented by the author with this web-based employee recruitment information system, the authors draw the conclusion that with the construction of this information system, the problem of employee recruitment becomes more effective. 
International Journal of Computer and Information System (IJCIS)

Peer Reviewed - International Journal

Vol :Vol. 02, Issue 02, May 2021

e-ISSN : 2745-9659

https://ijcis.net/index.php/ijcis/index

With this information system, applicants do not need to use paper to apply for jobs. And with this system, companies can inform more broadly about job vacancies.

\section{REFERENCES}

[1] Ameilia Zuliyanti Siregar dan Nurliana Harahap. (2019). Strategi Dan Teknik Penulisan Karya Tulis Ilmiah Dan Publikasi. Deepublish.

[2] Anggraeni, Y. E., \& Irviani, R. (2017). Pengantar Sistem Informasi (E. Risanto (ed.)). CV.ANDI OFFSET.

[3] Edi, F. R. S. (2016). Teori Wawancara Psikodignostik. yogyakarta : LeutikaPrio,2016.

[4] Elbadiansyah. (2019). ManajemenSumberDayaManusia. CV IRDH.

[5] Haqi, B. (2019). Aplikasi SPK Pemilihan DosenTerbaikMetode Simple Additive Weighting (SAW) Dengan Java (1st ed.). Deepublish

[6] Marjuni, S. (2015). Manajemen Sumber Daya Manusia (P. D. H. St. Haerani, S.E., M.Si. (ed.)). CV.SAH MEDIA.

[7] Ni'matuzahroh, \& Prasetyaningrum, S. (2018). observasi: teori dan aplikasi dalam psikologi. Universitas Muhammadiyah Malang.

[8] Sa'ad, M. I. (2020). Otodidak Web Programming: Membuat Website Edutainment. PT Gramedia Jakarta.

[9] Suprihadi, E. (2020). Sistem Informasi Bisnis Dunia Versi 4.0. ANDI OFFSET.

[10] Widodo, A. W., \& Kurnianingtyas, D. (2017). Sistem Basis Data (1st ed.). UB Press.

[11] Muryani, A. S., \& Muqorobin, M. (2020). Decision Support System Using Cloud-Based Moka Pos Application To Easy In Input In Orange Carwash Blulukan Flash N0. 110 Colomadu. International Journal of Computer and Information System (IJCIS), 1(3), 66-69.

[12] Rais, N. A. R., \& Saputra, R. (2020). Online Sales System Analysis of PT. Nutrifood Indonesia through the distributor CV. Trio Sukses Mandiri Solo With Nutrimart Home Delivery (NHD) Application. International Journal of Computer and Information System (IJCIS), 1(2), 40-46.

[13] Pujianto, H., \& Rokhmah, S. (2021). Analysis of" E-Patient UNS" Application System for Online Registration of UNS Hospital Patients. International Journal of Computer and Information System (IJCIS), 2(1), 9-12.

[14] Dwiyana, D., \& Muqorobin, M. (2021). Analysis of Adi Soemarmo Solo Airport Parking Payment System. International Journal of Computer and Information System (IJCIS), 2(1), 1-3.

[15] Efendi, T. F., \& Wihartati, A. P. (2021). Decision Support System for Share Investment Using The Capital Assetpricing Method (CAPM). International Journal of Computer and Information System (IJCIS), 2(1), 18-22. 